\title{
Comunicação política e midiatização: 0 embate de Bolsonaro com a imprensa
}

\section{Mayra Regina Coimbra}

Universidade Federal de Juiz de Fora, Programa de Pós-Graduação em Comunicação, Juiz de Fora, MG, Brasil

ORCID: http://orcid.org/0000-0003-1601-9315

\section{Deborah Luiza Vieira dos Santos}

Universidade Federal de Juiz de Fora , Programa de Pós-Graduação em Comunicação, Juiz de Fora, MG, Brasil

ORCID: https://orcid.org/0000-0002-0347-8638

\section{Luiz Ademir de Oliveira}

Universidade Federal de Juiz de Fora, Departamento de Comunicação Social, São João del-Rei, MG, Brasil ORCID: http://orcid.org/0000-0003-3959-980X

\section{Carla Fernandes Montuori}

Universidade Paulista, Programa de Pós-Graduação em Comunicação e Cultura das Mídias, São Paulo, SP, Brasil

ORCID: https://orcid.org/0000-0002-7625-8070

\section{Resumo}

O presente artigo discute a estrutura midiática contemporânea e a interação social mediada, por meio do encadeamento midiático que se dá entre o Twitter e a mídia impressa, representada pelos jornais Folha de S. Paulo e O Globo. Para tal, toma-se como objeto o episódio no qual o Presidente Bolsonaro afirmou que a jornalista Míriam Leitão integrava a luta armada durante a Ditadura Militar, questionando o fato de ela ter sofrido tortura durante o regime. Tal acontecimento gerou repercussão na mídia tradicional e nas micromídias - Twitter e Facebook. Para observar a ocorrência do encadeamento midiático entre as redes utilizou-se a Análise de Conteúdo mesclada à Análise de Enquadramento. A abordagem teórica se concentra em dois eixos: a midiatização e a circularidade das mensagens. $O$ trabalho concluiu que as ferramentas digitais, nesse caso o Twitter, viabilizam processos comunicativos de mão dupla e facilita a livre circulação de informações em escala global, ampliando o debate público.

\section{Palavras-chave}

Encadeamento Midiático; Midiatização; Micromídias; Mídia impressa 


\section{Introdução}

Nas sociedades antigas, o referencial de mundo e o conhecimento efetivavam-se por meio das narrativas religiosas e dos mitos, que eram repassados por meio da tradição oral entre os indivíduos pertencentes a um mesmo grupo social e familiar (RODRIGUES, 1990; THOMPSON, 2009). Com a ascensão da modernidade e a autonomização dos campos de saberes, coube ao campo midiático o papel de "homogeneizador" social (BOURDIEU, 2001; BERMAN, 1984). Os meios de comunicação passaram, portanto, a organizar o caos, reorganizar os fragmentos e dar sentido ao mundo, conferindo visibilidade aos fatos e aos atores sociais (RODRIGUES, 1990).

No entanto, se até algum tempo podíamos falar na centralidade da mídia, hoje se discute o fato de estarmos vivenciando a sociedade midiatizada. Isso ocorreu em decorrência, principalmente, da consolidação e popularização do acesso à internet e às mídias digitais. Essa ascensão tornou visível o processo no qual se passa de uma "sociedade dos meios" para uma "sociedade midiatizada", em que os receptores são também produtores, críticos e disseminadores de informação (FAUSTO NETO, 2010).

Braga (2012) afirma que as tecnologias digitais são fundamentais para a criação de novas possibilidades de midiatização para setores não midiáticos, havendo um vínculo entre produção e recepção. 0 autor ainda acrescenta que o processo de midiatização necessita da própria demanda social para ocorrer. No processo de midiatização, não se fala de um campo midiático, mas sim das diversas formas como os campos sociais são penetrados pela interação social midiatizada. No entanto, tal processo ataca a esfera da "legitimidade" dos campos sociais, fazendo com que eles se reelaborem de forma contínua.

Desse modo, se antes a mídia tradicional conservava a noção de verdade, tão enraizada na percepção social e no próprio modo como o campo jornalístico se constitui, agora nota-se que a internet e as redes sociais colocam em xeque o lugar de fala conquistado pelos veículos tradicionais como instância de verdade. Isto, de certa forma, desestabilizou as relações de poder existentes e consolidadas nos campos simbólicos. Entretanto, há que se ter cautela, porque não houve uma ruptura em termos de poder em relação aos sistemas midiáticos, mas reconfigurações, tendo em vista que os conglomerados de mídia continuam oligopolizados. Da mesma forma, compreende-se que o processo de midiatização não é algo recente, mas que foi intensificado. 
Nesse sentido, nota-se uma circularidade de informações, uma vez que a lógica das redes sociais implica uma rede de contatos horizontais, no qual todos se comunicam com todos. Esse processo de circularidade tem como consequência o que Primo (2008) chama de "encadeamento midiático", em que se nota um entrelaçamento de vozes (mídia de massa, mídia de nicho e micromídia), propiciado pelas rearticulações na estrutura midiática contemporânea.

Diante dessa nova ambientação, o presente trabalho analisa a estrutura midiática contemporânea e a interação social mediada tecnologicamente. Para tal, tem-se a polêmica envolvendo o presidente Jair Bolsonaro (sem partido) e a jornalista Míriam Leitão, ocorrida no dia 19 de julho de 2019. No episódio, Bolsonaro afirmou que a jornalista integrava a luta armada durante a ditadura militar e questionou se ela havia mesmo sofrido tortura durante o regime. 0 objetivo da pesquisa é discutir o encadeamento midiático (PRIMO, 2008) entre o Twitter e os jornais Folha de S. Paulo e O Globo. Não se trata de um caso isolado, mas de uma estratégia recorrente do governo Bolsonaro se colocar como o antissistema da política e deslegitimar o campo jornalístico. Dados coletados apontam que, nos 100 primeiros dias de governo, foram 38 postagens críticas à imprensa. 0 caso Miriam Leitão serve, nesse sentido, para ilustrar como este embate está ocorrendo.

\section{Da centralidade à sociedade midiatizada}

Com o advento da Modernidade, a instância comunicativa midiática foi assumindo um espaço de centralidade na vida social. Para Thompson (2009), há uma disseminação muito mais ampla das formas simbólicas e a emergência de novas formas de interação, mediadas tecnologicamente. Isso tende a se intensificar com os meios de comunicação massivos e mais especificamente no século XXI com as mídias digitais. Nesta mesma linha de análise, Rodrigues (1990) discute como a mídia assume um espaço de mediação social para os demais campos sociais, de modo a servir como referencial de mundo para a sociedade. Segundo o autor, o campo midiático avoca a tarefa de servir de mediador, fazendo uma transposição de linguagens de outras esferas para uma linguagem de fácil compreensão a fim de atingir o maior número de pessoas.

O surgimento de novas mídias provoca transformações sociais. Nesse sentido, surge o conceito de midiatização, o qual ainda está em construção, mas aponta essa transformação/aceleração dos processos sociais em decorrência da interferência dos meios 
de comunicação. Fausto Neto (2008) argumenta que, no período denominado "sociedade dos meios", as mídias tinham uma autonomia relativa, face à existência dos demais campos. Já na sociedade midiatizada, "a cultura midiática se converte na referência sobre a qual a estrutura-técnica-discursiva se estabelece, produzindo zonas de afetação em vários níveis da organização e da dinâmica da própria sociedade" (FAUSTO NETO, 2008, p. 93).

Desse modo, Fausto Neto (2008) argumenta que o surgimento e posterior disseminação do acesso à internet - redes sociais e blogs - fez com que passássemos de uma "sociedade dos meios", centrada nos meios de comunicação, na qual a transmissão da mensagem seguiria o caminho emissor para receptor; para uma "sociedade midiatizada", em que os receptores são ativos no processo da comunicação.

No entanto, esse processo de midiatização é um processo de dupla face, visto que a mídia se torna um campo "semi-independente" da sociedade, no qual os demais campos e instituições têm de se adaptar, obrigando, em maior ou menor grau, que os mesmos se submetam à sua lógica (BRAGA, 2012; HJARVARD, 2012). Os meios de comunicação moldam novos padrões de interação e, na midiatização, a própria mídia se confunde com os outros processos sociais, havendo uma virtualização da interação social (HJARVARD, 2012). A presença do campo midiático e suas instituições tornam-se tão intrínseca na sociedade que não se pode considerá-lo separado dos fatores culturais e sociais. Portanto, a sociedade midiatizada compreende a influência dos media nos processos sociais, no qual a própria mídia assume funções sociais antes oferecidas pelas instituições tradicionais.

Há que se destacar também outra alteração decorrente do processo de midiatização social. Ele ataca a esfera de "legitimidade" dos campos sociais, fazendo com que eles se reelaborarem de forma contínua (BRAGA, 2012). Se antes era necessário que acontecimentos fossem veiculados pela grande mídia para se tornarem notícias, agora as redes sociais, como o Twitter, Facebook, e sites atuam como fonte primária de propagação de informações.

\section{A complexidade do processo de circulação midiática e os efeitos sociais}

A partir dos anos 70, emerge um novo paradigma da comunicação, marcado pela circularidade, que entende que há uma interferência contínua do receptor no processo de produção das mensagens (FRANÇA, 2001). Isso se torna ainda mais evidente com as mídias 
digitais, já que o receptor pode se transformar num produtor de conteúdo, compartilhador, assumindo papéis bem diferenciados.

Segundo Fausto Neto (2010), a existência de novos processos de circulação de mensagens e de produção de sentidos são responsáveis por uma arquitetura comunicacional, que tem afetado as condições de vínculos entre produtores e receptores, propondo assim novos modos de interação entre instituições, mídias e atores sociais. Nas relações ente produção e recepção, cada vez mais complexas, ganha força o conceito de circularidade. Assim, "quando se trata de valores simbólicos e da produção e recepção de sentidos, o que importa mais é a circulação posterior à recepção. [...] 0 sistema de circulação interacional é essa movimentação social dos sentidos e dos estímulos produzidos inicialmente pela mídia" (BRAGA, 2006, p.28).

Nesse sentido, as investigações mostraram que a recepção existe e age. Dessa forma, as mídias passam a se situarem em uma problemática mais complexa e não mais aquela de sentido único. A transformação da sociedade dos meios para uma sociedade em vias de midiatização gera novas estruturas e dinâmicas relações entre produtores e receptores de discursos. Na sociedade dos meios, os estudos sobre a recepção mostram que o receptor faz tantas coisas outras, distintas daquelas que são estimadas pelos produtores. "Na 'sociedade em vias de midiatização', o receptor é re-situado em outros papéis na própria arquitetura comunicacional emergente" (FAUSTO NETO, 2010, p.6).

Conforme aponta Fausto Neto (2010), na sociedade em vias de midiatização um novo cenário sociotécnico é colocado em questão e constitui novas interações entre produção/recepção. Neste cenário, o conceito de circulação inicial que a concebia apenas como uma zona insondável, intervalo ou passagem, passa a funcionar como uma zona de indeterminação, seja como dispositivo ou como espaço gerador de potencialidades. "As intenções de origem perdem força, uma vez que estão entregues a outras dinâmicas que fazem com que produção e recepção não possam mais controlá-las, bem como os efeitos que presumem estabelecer sobre discursos" (FAUSTO NETO, 2010, p.9). Portanto, a linearidade inicial da circulação dá lugar à heterogeneidade.

Braga (2006) argumenta que essa característica de fluxo contínuo é de extrema relevância nos estudos da comunicação e um dos aspectos mais tocantes do processo de midiatização. Na medida em que as interfaces sociais se encadeiam crescentemente percebemos que as relações interacionais nos macro-ambientes de interação social - aqui inclui-se as redes sociais - deslocam-se do modelo conversacional (comunicação 
reverberante, de ida-e-volta) para um processo de fluxo contínuo, sempre adiante. Nesse sentido, já não é tão simples e óbvio distinguir "pontos iniciais" e "pontos de chegada", ou seja, já não é possível compreender a produção e a recepção como instâncias separadas. Os circuitos e os processos de circulação não se desenvolvem no vazio. Existe uma sociedade solidamente composta por instituições e estruturas historicamente elaboradas.

No âmbito do debate sobre circulação e interfaces, cabe aqui utilizar os estudos de Alex Primo (2008). Em sua obra, o autor discute sobre o impacto das interfaces digitais nos processos de circulação e debate de notícias. A partir de uma reflexão sobre a estrutura midiática contemporânea e a interação social mediada tecnologicamente, o autor apresenta o conceito de encadeamento midiático. 0 conceito de encadeamento midiático baseia-se na tipificação da mídia sugerida por Thornton (1996), que propõe três níveis midiáticos: mídia de massa, mídia de nicho e micromídia. Enquanto o primeiro e o segundo nível podem ser comparados, respectivamente, à tradicional classificação broadcasting e narrowcasting, a proposta do nível micromídia coloca-nos diante de uma grande descoberta. Thornton (1996) conceitua micromídia como um conjunto de mídias voltadas para pequenos públicos. No entanto, Primo (2008) salienta que, diante da emergência de interfaces cada vez mais participativas da Web 2.0, o conceito requer atualizações.

Se os folhetos e rádios livres apresentam dificuldades de produção e de distribuição, o mesmo não se pode dizer de blogs, microblogs e podcasts, que podem ter acesso global mesmo que tenham uma estrutura produtiva pequena e de baixo investimento. Logo, é preciso fazer algumas atualizações importantes. Segundo Primo (2008) é preciso que se compreenda a tipologia de Thornton para além da categorização de meios e levar em conta as condições de produção e recepção. Nos níveis massivos e de nicho, a produção depende de alto grau de investimento tanto em nível pessoal quanto em meios de produção. Os trabalhos são comumente divididos entre as pessoas na escala de produção, que dificilmente conhecem o próprio produto final. Os custos desse processo e da manutenção precisam ser pagos principalmente pela venda de espaços publicitários. Para que haja anunciantes, é preciso que os veículos garantam volumosas audiências. Diante da necessidade de atrair a atenção das massas, o que se percebe são mensagens definidas em conteúdo e formatos para o "denominador comum mais baixo". Já os produtos micromidiáticos são, muitas vezes, produzidos de modo quase artesanal e, às vezes, até por uma única pessoa, havendo assim grande intimidade dos produtores com o tipo de conteúdo produzido e também com suas audiências. 
No entanto, Primo (2008) ressalta que, ao considerar os níveis midiáticos existentes atualmente, percebe-se que já não se pode supor uma relação mutuamente excludente entre eles. Pelo contrário, o que se percebe é que um nível recorre constantemente a outro seja para se pautar, para expandir sua atuação diante do seu público ou até mesmo para inspirar relatos e críticas a serem veiculados. É esta inter-relação entre os diferentes níveis (mídia de massa, mídia de nicho e micromídia) que o autor chama de encadeamento midiático. Jenkins (2009) endossa esse pensamento ao argumentar que, se o paradigma da revolução digital acreditava que as novas mídias substituiriam as antigas, o paradigma da convergência admite que novas e antigas mídias irão interagir de formas cada vez mais complexas.

\section{Estudo de caso: a polêmica de Jair Bolsonaro com a jornalista Míriam Leitão}

As discussões sobre um novo paradigma da comunicação e a respeito de novos fluxos interativos entre produtores e receptores são fundamentais para o campo da Comunicação Política. Conforme explica Aggio (2011), desde a campanha de Barack Obama, em 2008, as mídias digitais passaram a ter um papel estratégico na relação entre representantes e eleitores. Isso vem impactando não somente as campanhas eleitorais, mas o que se conceitua como campanha permanente, entendida como a confluência da comunicação governamental com a comunicação eleitoral e partidária (MARTINS, 2016). Nesse sentido, tanto na disputa eleitoral de 2018 quanto nos seus seis primeiros meses de governo, Jair Bolsonaro (sem partido) tornou-se um rico objeto de análise para se pensar as novas configurações da política numa nova ambiência midiática marcada pelo uso recorrente das mídias digitais.

Jair Bolsonaro colecionou polêmicas ao longo de sua carreira política e, como presidente da República, não tem sido diferente. É notória, desde o período eleitoral, a tentativa de utilizar circuitos alternativos para destituir o poder do campo jornalístico. Essa destituição tem se configurado em constantes ataques à imprensa. Como exemplo, podemos citar alguns episódios, como o que aconteceu ainda no período eleitoral, em 18 de outubro de 2018, dez dias antes do segundo turno, quando a Folha de S. Paulo veiculou uma denúncia (MELLO, 2018) contra Bolsonaro sobre a prática ilegal de possíveis doações de empresas e empresários para pacotes de mensagens contra o PT no WhatsApp. Já no cargo 
de presidente, enfrentou outro embate com a Folha de S. Paulo, após a mesma divulgar reportagem (MATTOSO et al., 2019) sobre esquema de candidaturas laranja do PSL, então partido de Bolsonaro. Em contrapartida, a mídia tem dado sinais de que não vai aceitar que um político questione o funcionamento de seu campo e tem adotado uma postura crítica em relação ao governo. 0 quadro "Isso a Globo não mostra", uma inovação criada no programa Fantástico, apresenta um compilado de imagens com as principais notícias da semana, em uma mistura de memes ${ }^{1}$, cenas de novelas e piadas.

No dia 19 de julho de 2019, o presidente Bolsonaro envolveu-se em outra polêmica com a imprensa. Durante um café da manhã com jornalistas estrangeiros, ao ser questionado sobre o episódio em que Míriam Leitão e seu marido, Sérgio Abranches, foram excluídos da 13a Feira do Livro de Jaraguá do Sul (SC), sob a alegação de que os convidados repudiavam à presença deles devido ao seu "viés ideológico", Bolsonaro se disse aberto à liberdade de imprensa. 0 presidente ainda disse que Míriam deveria aprender a receber críticas e afirmou que ela integrava a luta armada durante a ditadura militar. Ele chegou a questionar se ela havia mesmo sofrido tortura durante o regime e acrescentou que Míriam serve a um império que não tem mais aquela força que tinha no passado, em referência à mídia tradicional (nesse caso, as Organizações Globo). E, com o celular na mão, o presidente exaltou o que chamou de mídia completamente livre, em referência às redes sociais.

Mais do que espaço na grande mídia, tal declaração motivou uma ampla discussão no ciberespaço. Sendo assim, a pesquisa em questão visa analisar a repercussão do embate entre o presidente e a instância midiática, buscando avaliar o impacto das interfaces digitais, mais especificamente o Twitter, nos processos de circulação e debate de notícias. 0 objetivo é discutir o encadeamento midiático (PRIMO, 2008) e analisar as rearticulações na estrutura midiática contemporânea.

\subsection{Metodologia e corpus de análise}

Para observar a ocorrência do encadeamento midiático, acompanhou-se como o caso Bolsonaro e Míriam Leitão foram noticiados e discutidos em dois jornais nacionais Folha de S. Paulo e O Globo - e no Twitter. A escolha deste caso se deu por envolver dois objetos que estão sendo discutidos em outras pesquisas sob perspectiva mais ampla: o

\footnotetext{
1 Meme é um termo grego que significa imitação. 0 termo é bastante conhecido e utilizado no "mundo da internet", referindose ao fenômeno de "viralização" de uma informação, ou seja, qualquer vídeo, imagem, frase, ideia, música e etc, que se espalhe entre vários usuários rapidamente, alcançando muita popularidade.
} 
campo político e a instância midiática. A escolha desses dois veículos se justifica por serem os dois jornais de maior circulação (PODER360, 2018) no país, tanto no meio impresso quanto no meio digital.

Durante o mesmo período de análise dos jornais (19 e 20 de julho de 2019), foram coletados, por meio do software TAGS v 6.1.9. (especializado em buscas de hashtag e perfis no Twitter), os tweets que mencionavam \#MíriamLeitão e \#JornalNacional. A escolha destas hashtags se deu pelo fato delas terem se mantido nos Trending Topics durante o dia do fato. Com estes dados, avaliou-se: (1) quantos tweets criticavam a cobertura da mídia; (2) quantos tweets comentavam positivamente a atuação da cobertura da mídia; (3) quantidade de tweets que emitiam opiniões pessoais sobre o caso (contra ou a favor); e, dentre estes, (4) quantos ofereciam links para outros sites. Os textos que, apesar de terem as tags \#MíriamLeitão e \#JornalNacional, não se referiam ao episódio estudado, foram classificados na categoria "outros". Vale destacar que um mesmo tweet pode se encaixar em mais de uma dessas categorias pela própria lógica da rede.

\subsection{O discurso dos meios de comunicação de massa}

Foram analisadas as versões impressas e digitais dos jornais Folha de S. Paulo e 0 Globo nos dias 19 e 20 de julho de 2019, a fim de verificar como o caso reverberou nestes espaços. 0 jornal Folha de S. Paulo publicou apenas uma notícia sobre o assunto no dia 20 de julho. Com o título "Para Bolsonaro, imprensa distorce suas declarações e sente saudades do PT" (URIBE, 2019), o jornal apresenta as explicações feitas pelo presidente sobre o ataque à jornalista Míriam Leitão e sobre outras declarações polêmicas que fez, como a de que não há fome no Brasil e o fato de ter chamado os governadores nordestinos de "paraíbas".

Vale ressaltar que o próprio jornal recorre ao Twitter do presidente para obter a declaração sobre o fato e para a construção da matéria. Nota-se, como discutido anteriormente, as mudanças e as reconfigurações sofridas no campo da comunicação em função dessa nova ambiência, na qual os fluxos midiáticos estão sendo marcados por alterações nas suas dinâmicas. Se antes a mídia era tida como campo legítimo de fala, a única capaz de produzir mensagens e informações, agora se observa um processo inverso. Ela perde seu lugar de detentora do discurso da verdade, deixa de ser apenas produtora de conteúdo e passa a se pautar por ferramentas de comunicação da cultura digital, para a 
construção de suas notícias. Vale destacar que o presidente Bolsonaro, desde o período de campanha e agora mais intensamente, tem se dedicado a utilizar circuitos alternativos para a destituição do poder do campo jornalístico.

O jornal 0 Globo, por sua vez, publicou duas notícias sobre o fato, ambas no dia 20 de julho, com os títulos "Bolsonaro usa informações falsas para atacar a jornalista Míriam Leitão" (O GLOBO, 2019) e "Em defesa da liberdade de expressão" (PEREIRA, 2019). A primeira matéria trata da versão da jornalista Míriam Leitão sobre o fato, na qual ela tem a oportunidade de se defender. Anexo a essa versão, o jornal apresenta também uma nota do Grupo Globo, em que este afirma que os ataques sofridos tanto no passado, pelo Partido dos Trabalhadores e pelo ex-presidente Lula, como agora, por Jair Bolsonaro, são a prova das virtudes da jornalista, da sua independência profissional. A nota afirma ainda ser esta a parte fundamental que move a emissora e os profissionais que nela estão e se solidarizam com a companheira.

"Em defesa da liberdade de expressão" trata-se de um artigo escrito por Merval Pereira $^{2}$, em que ele menciona as declarações polêmicas do presidente em relação à jornalista Míriam e sobre a intervenção do governo na Agência Nacional de Cinema (Ancine). Além de se mostrar revoltado com a atitude de Bolsonaro, Merval relembra os ataques desferidos à Míriam e a outros jornalistas por petistas e pelo ex-presidente Lula (PT), quando este ocupava o cargo presidencial. Ele destaca o alastramento dessa cultura do ódio em relação à imprensa brasileira e afirma ser necessário estar atento à defesa da liberdade de expressão e condena qualquer forma de censura, venha de onde vier. "Qualquer ameaça à livre expressão e à pluralidade de manifestações culturais constitui um lamentável retrocesso a um obscurantismo que não deve ser tolerado" (O GLOBO, 2019).

Tais matérias reforçam as afirmações feitas por Braga (2012) de que os campos de saberes, ao se verem em risco, tentam se reorganizar para fim de retomar a legitimidade e o poder que antes lhes eram confiados. Ao ser atacada e colocada em xeque, a mídia se organiza para também atacar e recuperar seu lugar de destaque.

\footnotetext{
2 Merval Pereira participa do Conselho Editorial do Grupo Globo. É membro das Academias Brasileira de Letras, Brasileira de Filosofia e de Ciências de Lisboa.
} 


\subsection{0 discurso da micromídia de comunicação digital: Twitter}

O total de tweets postado no dia 19 de julho de 2019 com \#MíriamLeitão foi de 424. Já no dia seguinte, o total foi de 355 tweets. Os tweets do dia 19 não puderam ser analisados em sua maioria, visto que eles se referiam ao episódio em que Míriam Leitão entrevistou Fernando Haddad para o canal Globo News, na noite do dia 18 de julho.

Quase nenhum debate sobre a polêmica envolvendo Jair Bolsonaro e a jornalista Míriam Leitão apareceu no Twitter no dia 19. Dos 424 tweets postados com \#MíriamLeitão, 423 (99\%) estavam se referindo à repercussão da entrevista com Haddad. Apenas quatro tweets $(1 \%)$ emitiam a opinião dos internautas sobre o caso aqui estudado e todas as opiniões apresentadas eram contra a jornalista. Um único tweet $(0,2 \%)$ foi identificado como crítico à mídia. Do total de 427, 350 tweets (82\%) apresentavam links para outros sites; na maioria das vezes, o link direcionava para a entrevista de Fernando Haddad com Míriam Leitão. Não é o que nos interessa nesse estudo.

No dia 20 de julho, de um total de 355 tweets com a \#MíriamLeitão, identificou-se 65 postagens (18\%) com tom crítico a respeito da cobertura midiática sobre o caso e 94 tweets (26\%) com comentários positivos em relação à atuação midiática. A maior parte dos tweets estava relacionada à opinião das pessoas em relação ao fato, somando 187 tweets (53\%). Destes, 62 eram contra a figura da jornalista Míriam Leitão e 125 a favor da jornalista. A categoria "outros" somou um total de 68 tweets (19\%). Do total de 355 tweets, 101 (28\%) ofereciam links para outros sites.

Nota-se que a hashtag na discussão do caso Jair Bolsonaro e Míriam Leitão acionou em maior grau a opinião pessoal dos usuários da rede, presente em $53 \%$ dos tweets. É importante notar que os internautas não se limitaram apenas a reproduzir notícias e oferecer links para grandes sites e portais jornalísticos. Neste dia, o acionamento de links correspondeu a apenas $28 \%$. Mais do que isso, os números mostram que as pessoas se interessavam em dar sua posição sobre o assunto (187 tweets - 53\%) e em se posicionar, seja criticamente ou não, sobre a atuação da mídia. Isso nos revela algo muito importante. Se antes a imprensa era tida como "cão de guarda" (watchdog), que agia em defesa dos interesses dos cidadãos e buscava promover um controle extremo das atividades do governo em nome dos cidadãos (ALBUQUERQUE, 2010), agora, com o uso das redes sociais, o público passa também a exercer a função watchdog em relação não só ao campo político, mas também ao campo jornalístico. 
O total de tweets postado no dia 19 de julho de 2019 com \#JornalNacional foi de 153. Já no dia seguinte, o total foi de 1.173 tweets. Os tweets do dia 19 não puderam ser analisados visto que todos eles se encaixaram na categoria "outros", pois estavam se referindo a outras notícias divulgadas pelo Jornal Nacional naquela noite, como o ataque de Bolsonaro à Ancine, a escolha do seu filho Flávio como embaixador nos Estados Unidos, além de postagens replicando a audiência dos canais televisivos de comunicação naquele dia.

No dia 20 de julho, de um total de 1.173 tweets com \#JornalNacional, identificou-se 332 postagens (28\%) com tom crítico a respeito da cobertura midiática sobre o caso e 610 tweets (52\%) com comentários positivos em relação à atuação midiática. A opinião das pessoas em relação ao fato somou 219 tweets (19\%). Destes, 41 eram contra a figura da jornalista Míriam Leitão e 178 a favor. A categoria "outros" somou um total de 164 tweets (14\%). Do total de 1.173 tweets, 806 (69\%) ofereciam links para outros sites.

Como apontado na análise dos veículos noticiosos, observa-se que eles se pautaram em ferramentas de comunicação digital para produção de conteúdo, mas o contrário também aconteceu, o que evidencia a noção de circularidade da comunicação e de que os receptores exercem poder de influência sobre a mídia (THOMPSON, 2009; BRAGA, 2006). A categoria mais acionada neste dia, com essa hashtag, foi o uso de links para outros sites, em especial o link que direcionava ao vídeo da nota divulgada pela Rede Globo e lida pela apresentadora Renata Vasconcelos ao vivo no fim da edição do Jornal Nacional.

Assim como afirma Primo (2008), tanto as mídias de massa como as micromídias estão envolvidas em uma relação simbiótica, em um processo de encadeamento, na qual blogs podem se basear na mídia de massa, bem como a mídia de massa pode se basear em blogs. 0 que se percebe neste estudo de caso é que, ao comentar um fato no Twitter, os internautas reproduzem discussões apresentadas no plano dos media e inclusive compartilham o seu conteúdo na rede, por meio de links. Isso reforça também o argumento da circularidade apresentado por França (2001) e Braga (2012), de que as mídias digitais facilitaram o processo de interferência contínua do receptor no processo de produção das mensagens. Nota-se, nesse caso, que os receptores se transformaram também em produtores e compartilhadores de conteúdo, assumindo papéis antes improváveis.

Ao atacar a mídia, os usuários da rede utilizam fortemente o argumento de que o Jornal Nacional e a Rede Globo não são imparciais. Os ataques feitos à jornalista Míriam Leitão, em sua maioria, têm esse mesmo tom. 0 que se percebe é que os campos antes 
considerados uniformes e dotados de autonomia, agora se encontram mais fragilizados em decorrência da dinâmica de fluxos e atravessamentos que lhes são inerentes dos processos ocorridos atualmente. O campo da comunicação é um exemplo. Por muito tempo, foi considerado um campo central, por onde outros campos circulavam para que fizessem sentido. Tais evidências colocam em xeque também as discussões sobre a hegemonia da Globo na condição de maior conglomerado de mídia do país. Se, na era das mídias massivas, a TV era detentora de grande poder simbólico, mesclado aos poderes político e econômico, o que se percebe, nos dias atuais, é uma quebra deste poder em função de uma grande variedade de veículos midiáticos. São novos circuitos informativos e comunicacionais que entram em disputa com as mídias tradicionais, sem, claro, negligenciar o poder que os conglomerados midiáticos ainda mantêm num país como o Brasil, em que há uma forte concentração em poucos grupos, como a Globo (LIMA, 2006).

Nesse sentido, atualmente, tal perspectiva já se encontra ameaçada pelos atravessamentos do processo de circulação, que recentemente tem colocado em xeque os meios tradicionais em decorrência das redes sociais. 0 sentido de verdade, antes atribuído inerentemente à mídia, hoje, em alguns casos, se vê transferido a outros campos e a outras plataformas. E mais: a própria mídia tem sido objeto de desconfiança por parte dos indivíduos.

\section{Considerações finais}

A partir do material analisado, foi possível observar como as ferramentas digitais, nesse caso o Twitter, viabilizam processos comunicativos de mão dupla. Enquanto a mídia massiva sempre trabalhou no modelo um para muitos, as tecnologias digitais fazem emergir o modelo de comunicação muitos-muitos. Qualquer um que tenha acesso à internet pode dizer alguma coisa, por um investimento muito baixo se comparado às demandas econômicas necessárias para a abertura e manutenção dos meios de comunicação de massa. Por meio da análise, foi possível observar como o material produzido por indivíduos anônimos foram amplamente difundidos e compartilhado nas redes.

Assim, é possível inferir que existe atualmente uma relação simbiótica entre os níveis midiáticos (mídia de massa, mídia nicho e micromídia). Essa relação consiste em um jogo de forças, no qual ora a mídia de massa se abastece do material presente na micromídia e ora o inverso acontece. Não há como negar também que as interfaces digitais propiciaram 
uma alteração significativa no processo de comunicação. 0 processo de circulação, antes compreendido apenas como passagem de algo do emissor ao receptor, alterou-se e trouxe importantes mudanças que se refletiram socialmente. Com a percepção de que agora os receptores são indivíduos ativos, capazes não só de receber, mas também produzir informação, a circulação passa a ser vista como o espaço do reconhecimento e também dos desvios produzidos pela apropriação dos sujeitos.

O desenvolvimento das mídias digitais facilitou a livre circulação de informações em escala global, ampliou o debate público sobre assuntos relevantes, como também irrelevantes, e permitiu a exposição de opiniões críticas por pessoas sem qualquer formação jornalística ou envolvimento com instituições midiáticas. No entanto, cabe ressaltar que não se acredita que foi atingido um estágio de transparência e que as mídias tradicionais perderam sua força. 0 que pode ser afirmado é que, neste espaço, produtores e receptores se encontram em jogos complexos, na qual há uma mudança estrutural evidente e que merece ser investigada. Inegavelmente, essas novas condições de circulação acabam afetando as lógicas das instituições antes tidas exclusivamente como produtoras de conteúdo, fazendo com que se organizem para uma adaptação em função dessa nova ambiência.

\section{Referências}

AGGIO, C. As campanhas políticas no Twitter: uma análise do padrão de comunicação política dos três principais candidatos à presidência do Brasil em 2010. In: Congresso da Associação Brasileira de Pesquisadores em Comunicação e Política, 2011. Anais... Rio de Janeiro, RJ: IV Compolítica, 2011, v. 4, p. 1-24.

ALBUQUERQUE, Afonso de. As três faces do quarto poder. In: MIGUEL, Luís Felipe \& BIROLI, Flávia (org.). Mídia, representação e democracia. São Paulo: HUCITEC, 2010. 92-104.

BERMAN, Antoine. L'épreuve de l'étranger: culture et traduction dans l'Allemagne romantique. Paris: Gallimard, 1984.

BOURDIEU, Pierre. 0 poder simbólico. Rio de Janeiro: Bertrand Brasil, 2001.

BRAGA, José Luiz. Circuitos versus campos sociais. In: MATTOS, M.A.; JANOTTI JÚNIOR, J.; JACKS, N. (orgs). Mediação \& Midiatização. Salvador: EDUFBA, 2012. p. 29-52.

BRAGA, José Luiz. A sociedade enfrenta sua mídia: dispositivos sociais de crítica midiática. São Paulo: Editora Paulus, 2006. 
FAUSTO NETO, Antônio. Fragmentos de uma analítica da midiatização. Matrizes, São Paulo, v. 1 , n. 2, p. 89-105, 2008.

FAUSTO NETO, Antônio. A circulação além das bordas. In: FAUSTO NETO, Antônio; VALDETTARO, Sandra (orgs). Mediatización, Sociedad y Sentido: diláogos entre Brasil y Argentina. Rosario: Departamento de Ciências da Comunicación, Universidad Nacional de Rosario, 2010. p. 2-15.

FRANÇA, Vera Veiga et al. Teorias da Comunicação. Petrópolis: Vozes, 2001.

HJARVARD, Stig. Midiatização: teorizando a mídia como agente de mudança social e cultural. Matrizes, São Paulo, v. 5, n. 3, p. 53-91, 2012.

JENKINS, Henry. Cultura da Convergência. São Paulo: Aleph, 2009.

LIMA, Venício de. Mídia. Crise política e poder no Brasil. São Paulo: Perseu Abramo, 2006.

MARTINS, Thamiris Franco. A Construção da imagem de Dilma Rousseff (PT) na esfera midiática: dissonâncias e convergências narrativas entre a presidente e a candidata à reeleição. Dissertação (Mestrado em Comunicação Social). Curso de Pós-Graduação em Comunicação da Universidade Federal de Juiz de Fora, Juiz de Fora, 2016.

MATTOSO, Camila et al. Bebianno é demitido e caso dos laranjas do PSL leva a primeira queda de ministro do governo Bolsonaro. Folha de S. Paulo, São Paulo; Recife; Brasília. 18 fev. 2019

MELLO, Patricia Campos. Empresários bancam campanha contra o PT pelo WhatsApp.

Folha de S. Paulo, São Paulo. 18 out. 2018.

O GLOBO. Bolsonaro usa informações falsas para atacar a jornalista Míriam Leitão. Rio de Janeiro. 19 jul. 2019.

PEREIRA, Merval. Em defesa da liberdade de expressão. O GLOBO. 20 jul. 2019.

PODER360. Tiragem impressa dos maiores jornais perde 520 mil exemplares em 3 anos. 31 jan 2018. Disponível em: https://www.poder360.com.br/midia/tiragemimpressa-dos-maiores-jornais-perde-520-mil-exemplares-em-3-anos/. Acesso em: 2 nov. 2018.

PRIMO, Alex. A cobertura e o debate público sobre os casos Madeleine e Isabella: encadeamento midiático de blogs, Twitter e mídia massiva. Revista Galáxia, São Paulo, v. 16, p. 43-59, 2008.

RODRIGUES, Adriano Duarte. Estratégias de Comunicação. Lisboa: Presença Editorial, 1990.

THOMPSON, John B. A mídia e a modernidade: uma teoria social da mídia. Petrópolis, RJ: Vozes, 2009. 
THORNTON, Sarah. Club Cultures: Music, Media and Subcultural Capital. Hanover: Wesleyan University Press, 1996.

URIBE, Gustavo. Para Bolsonaro, imprensa distorce suas declarações e sente saudades do PT. Folha de S. Paulo, Brasília. 20 jul. 2019

\title{
Political communication and mediatization: Bolsonaro's clash and the press
}

\begin{abstract}
This article discusses the contemporary media structure and the mediated social interaction, through the media linkage that takes place between Twitter and the print media, represented by the newspapers Folha de S. Paulo and O Globo. For this purpose, the episode in which President Bolsonaro stated that journalist Míriam Leitão was part of the armed struggle during the Military Dictatorship, questioning the fact that she had suffered torture during the regime, is taken as an object. This event generated repercussions in traditional media and micromedia - Twitter and Facebook. To observe the occurrence of media linkage between networks, Content Analysis was used, combined with Framework Analysis. The theoretical approach focuses on two axes: mediatization and the circularity of messages. The work concluded that digital tools, in this case Twitter, enable two-way communication processes and facilitate the free circulation of information on a global scale, expanding public debate.
\end{abstract}

\section{Keywords}

Media Enchainment; Mediatization; Micromedia; Press media

\section{Autoria para correspondência}

Mayra Regina Coimbra

mayrarcoimbra@gmail.com

\section{Como citar}

COIMBRA, Mayra Regina; SANTOS, Deborah Luiza Vieira dos; OLIVEIRA, Luiz Ademir de; MONTUORI, Carla Fernandes. Comunicação política e midiatização: o embate de Bolsonaro com a imprensa. Intexto, Porto Alegre, n. 52, e-98933, jan./dez. 2021. DOI: http://dx.doi.org/10.19132/1807-8583202152.98933 